\title{
DEGRADATION OF CHLOROPHYLL LUMINESCENCE IN PLANTS
}

\author{
O.V. VAKULENKO,${ }^{1}$ O.O. GRYGORIEVA, ${ }^{2}$ O.I. DACENKO ${ }^{1}$ \\ ${ }^{1}$ Taras Shevchenko National University of Kyiv, Faculty of Physics \\ (4, Academician Glushkov Prosp., Kyiv 01601, Ukraine; e-mail: lesoto@ukr. net) \\ ${ }^{2}$ Taras Shevchenko National University of Kyiv, Faculty of Biology \\ (2, Academician Glushkov Prosp., Kyiv 01601, Ukraine)
}

PACS 78.55. Kz

(C) 2012

The chlorophyll photoluminescence intensity degradation of Vallisneria spiralis L. water plant is studied. It is shown that the degradation curve is rather well described by a sum of two hyperbolic functions. The rate of intensity degradation reduces at low temperatures. At room temperature, a slow restoration of the luminescent system is observed after the irradiation has been ceased. No restoration is detected at the liquid nitrogen temperature. A simplified model which describes the luminescence degradation according to the quadratic law is suggested.

\section{Introduction}

The modern ecological investigations require reliable express-methods for the estimation of a functional state of living organisms. The luminescent method based on the analysis of red photoluminescence, whose centers are chlorophyll $a$ molecules [1], has been successfully used in the plant diagnostics for a long time.

The chlorophyll content in cell chloroplasts is known [2] to be directly dependent on the plant functional state, and, therefore, their luminescent properties can be not only the qualitative characteristic of viability, but also the quantitative one. Moreover, one of the unquestionable advantages of this method is its contactlessness, which makes it possible to perform investigations distantly $[3,4]$ and without any detriment to the object.

It is known [5], however, that the noticeable degradation of the intensity with time can be observed under excitation of the chlorophyll photoluminescence in plants. As a result, this phenomenon can affect the data obtained during the measurements. So, the researchers are faced with a problem of reliability of the results derived by the luminescent method of plant diagnostics. In this connection, it seems necessary to study the mentioned phenomenon in detail, which this work is devoted to.

\section{Experiment}

The leaf fragments of the higher water plant Vallisneria spiralis L. were used as the samples. The leaves were placed in a cuvette with water for the measurements at room temperature, while, at low temperatures, the samples were placed in a cryostat.

The luminescence was excited by the emission of an LGN-402 argon-ion laser with a wavelength of $488 \mathrm{~nm}$, the power density was about $200 \mathrm{~mW} / \mathrm{cm}^{2}$ in all cases.

The photoluminescence (PL) spectra were measured in the range of chlorophyll molecule emission, the spectral width of the device slit did not exceed $2 \mathrm{~nm}$.

The PL intensity degradation dynamics was measured under the same conditions as the spectra, the wavelength being fixed at the band peaks. The time constant of the registration system is about $1 \mathrm{~s}$.

\section{Results}

Two bands of chlorophyll $a$ emission with peaks at 740 and $685 \mathrm{~nm}$ are observed at room temperature in the PL spectra of $V$. spiralis L. (Fig. 1). According to the literature [6], the 740-nm band is related to molecules in the photosystem (PS) I and the 685-nm band, dominating in the spectrum, is caused by PS II of chloroplasts. The band of PS I predominates in the spectrum at the liquid nitrogen temperature, its peak being shifted by $10 \mathrm{~nm}$ to short waves.

Under the prolonged illumination of a plant by the excitation light, it has been found that the PL intensity decreases monotonously with time. The degradation dynamics of the emission intensity at the main band peaks of chlorophyll $a$ luminescence at room temperature is presented in Fig. 2. On can see that the PL efficiency decrease occurs rather rapidly, the intensity drops by a half just 1 to 2 min after the illumination start. In doing so, the decay process at the $685-\mathrm{nm}$ wavelength (PS II) proceeds slightly faster than that for the 740-nm band 


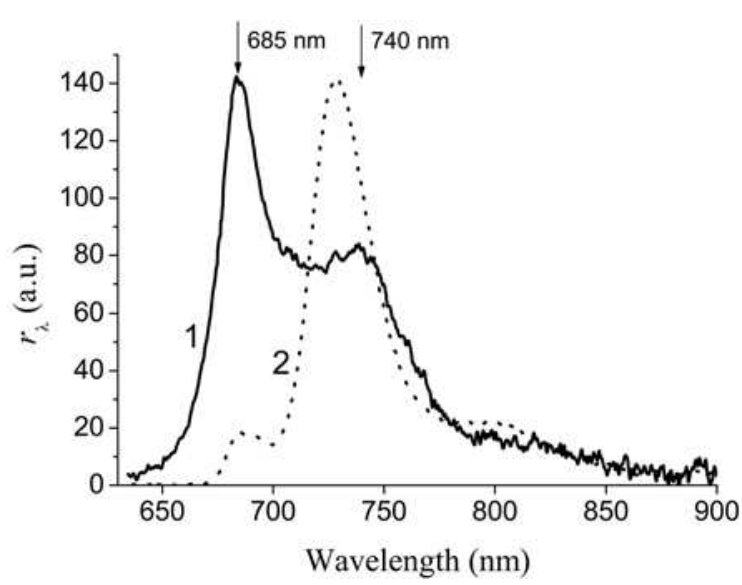

Fig. 1. Luminescence spectra of $V$. spiralis $\mathrm{L}$. at room temperature (1) and $85 \mathrm{~K}$ (2). The spectral density of emission energy is plotted as the ordinate

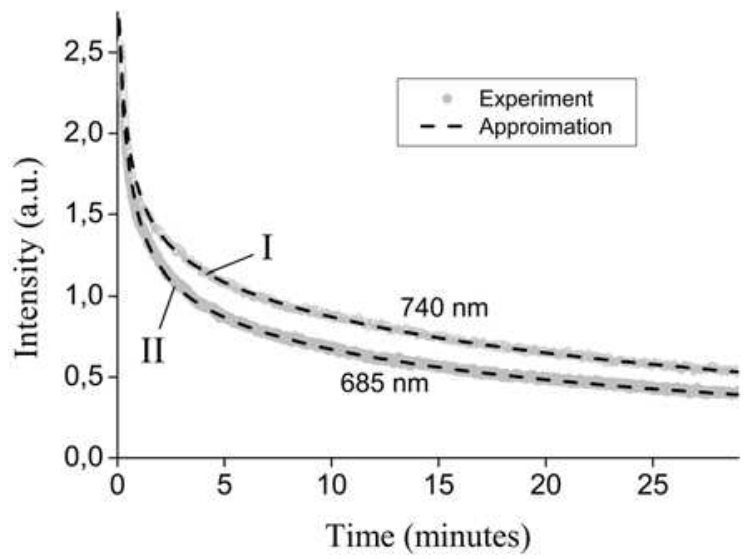

Fig. 2. Degradation dynamics of the $V$. spiralis $\mathrm{PL}$ at room temperature and the data approximation by the analytic function (1) with parameters $A_{1}=1.75, \tau_{1}=0.47, A_{2}=1.12, \tau_{2}=24$ (I) and $A_{1}=2.00, \tau_{1}=0.50, A_{2}=0.85, \tau_{2}=21$ (II)

(PS I). The intensity degradation for both bands slows down at the liquid nitrogen temperature (Fig. 3).

It is necessary to say that the dynamics of intensity degradation cannot be described by a simple law such as the exponential or hyperbolic one. It is rather well described by a sum of two exponents

$I=I_{\infty}+A_{1} \exp \left(-t / \tau_{1}\right)+A_{2} \exp \left(-t / \tau_{2}\right)$

or a sum of two hyperbolic functions

$I=\frac{A_{1}}{1+t / \tau_{1}}+\frac{A_{2}}{1+t / \tau_{2}}$.

Here, $A_{1}, A_{2}, \tau_{1}, \tau_{2}$, and $I_{\infty}$ are constants. It should be noted that, in the latter case, the theoretical curve

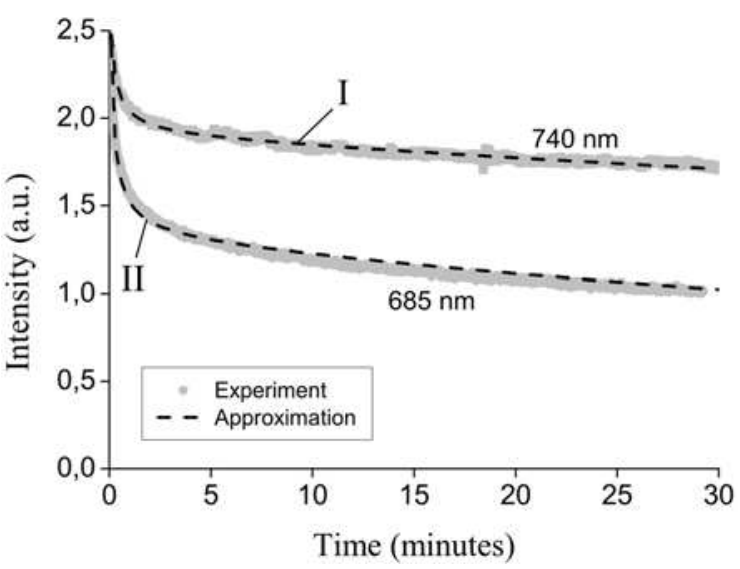

Fig. 3. Degradation dynamics of the PL at $85 \mathrm{~K}$ and the data approximation by function (1) with parameters $A_{1}=0.73, \tau_{1}=0.25$, $A_{2}=1.90, \tau_{2}=260(\mathrm{I})$ and $A_{1}=1.40, \tau_{1}=0.18, A_{2}=1.32$, $\tau_{2}=100(\mathrm{II})$

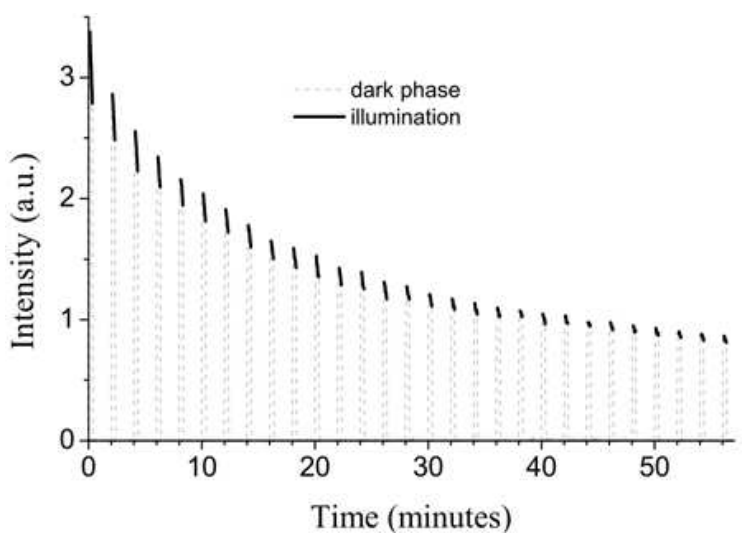

Fig. 4. Degradation dynamics of the 685-nm PL intensity under the interrupted excitation

corresponds better to the experimental data, and one has to fit only four constants instead of five in the sum of two exponents.

A slow restoration of the luminescent system is observed, after the irradiation has been stopped. At this point, indicative are the experiments with interrupted excitation. The laser irradiation is turned on for 20second-long periods every $2 \mathrm{~min}$. The results for the 685-nm band are presented in Fig. 4 (the data for the $740 \mathrm{~nm}$-band are similar). The PL intensity at the start of each subsequent turning-on is higher than that at the end of the previous one. This is well noticeable if the darkening periods are erased from the time sequence of the data (Fig. 5).

In the Figure, one can see that the results obtained under the interrupted excitation approximate the curve for the continuous one when the observation time in- 


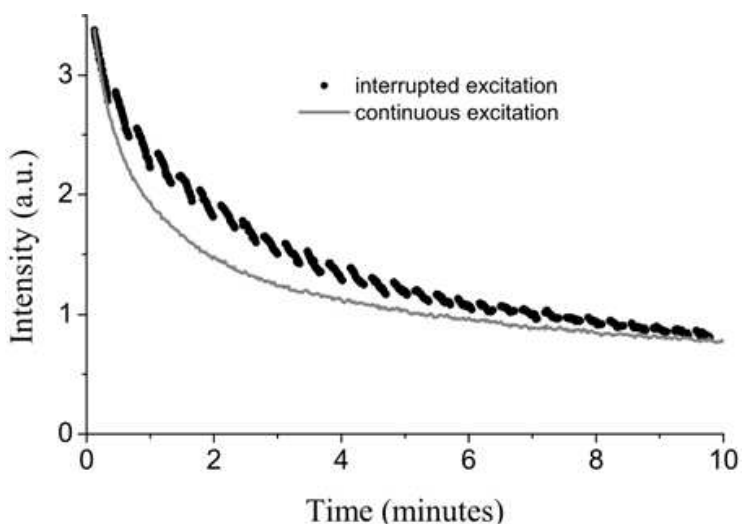

Fig. 5. Data of Fig. 4 with erased darkening periods compared to the data of continuous excitation

creases. This means that the restoration ability of the luminescent system gradually comes to naught.

Similar experiments were carried out at the liquid nitrogen temperature. As it turned out, no intensity restoration is detected during the darkening phase or it occurs too slowly to be noted under the conditions of our experiment. Anyway, the curve with erased darkening periods almost coincides with the degradation one for the continuous excitation.

\section{Discussion}

A simplified model which can describe the intensity degradation dynamics is formulated below. Let us suggest, besides of the monomolecular radiative recombination, the possibility of the non-radiative one. Let the latter happen with participation of two excited molecules, which, as a result, obtain the positive and negative charges, i.e., according to the scheme $M^{*}+M^{*}=M^{+}+M^{-}$. We supposed that the ionized molecules cannot participate in the luminescence.

Let $N$ be the total number of chlorophyll molecules, $N_{0}$ of them are in the ground electron state and $N^{*}$ in the excited one. In addition, a part of the excited molecules can transfer to an ionized state $\left(N^{+}\right.$and $\left.N^{-}\right)$due to the interaction. If we exclude other possible channels of ionization from consideration, we would obtain $N^{+}=N^{-}$. The balance equation will be as follows:

$N=N_{0}+N^{*}+2 N^{-}$

The supposed scheme of electron levels and possible transitions between them is shown in the inset to Fig. 6 . The molecule excitation probability $g$ is proportional to the incident irradiation intensity. The probability of the

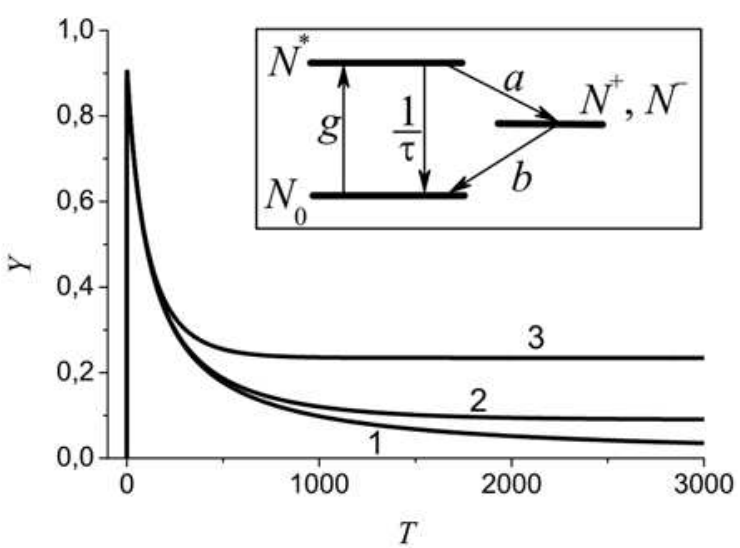

Fig. 6. Calculated curves of degradation for parameters $G=10$, $A=10^{-2}$ and $B=0(1), 10^{-4}$ (2) and $10^{-3}$ (3). A possible scheme of electron transitions in a molecule of chlorophyll is shown in the inset

reverse process, i.e., the emission of a luminescent photon, is $1 / \tau$, where $\tau$ is the molecule lifetime in the excited state. The interaction of two excited molecules can cause their transition to the ionized state, let the parameter of this process be signed as $a$. The ionization process occurs rather slowly, therefore, $a / \tau \ll 1$. Let us suppose that the deionization process is characterized by the parameter $b$. As a result of this process, two ionized molecules can transit to the ground state. According to the experimental data, this process is rather slow, at any case, $b \ll a$.

The transition dynamics is described by the system of differential equations

$\frac{d N_{0}}{d t}=-g N_{0}+\frac{N^{*}}{\tau}+b N^{+} N^{-}$

$\frac{d N^{*}}{d t}=g N_{0}-\frac{N^{*}}{\tau}-a\left(N^{*}\right)^{2}$.

Taking the relation $N^{+}=N^{-}$and the balance equation (2) into account and denoting $T=t / \tau, X=N_{0} / N$, $Y=N^{*} / N, G=g \tau, A=a N \tau$ and $B=b N \tau / 4$, one can rewrite the system in the dimensionless form:

$\frac{d X}{d T}=-G X+Y+B(1-X-Y)^{2}$,

$\frac{d Y}{d T}=G X-Y-A Y^{2}$

Here, the luminescence intensity is described by the parameter $Y$.

The analytic solution of the system of quadratic differential equations seems to be difficult. The solution 
by the computational method of simple iterations shows that, ignoring the deionization processes $(B=0)$, the dynamic dependence of the luminescence intensity, as expected, firstly increases rapidly according to the exponential law $Y=Y_{0}[1-\exp (-T)]$, reaches a maximum, and further decreases by the hyperbolic law (Fig. 6) down to zero $\left(Y_{\infty}=0\right)$. In particular, curve 1 for $B=0$ practically coincides with the function $Y=$ $0.9 /(1+T / 120)$. In turning the ionization process on $(B \neq 0)$, the hyperbolic dependence is broken at the final stage, and the curve flattens out at $Y_{\infty}>0$, which is not confirmed by the experiment.

The calculations performed allow us to suppose that the degradation mechanism is, indeed, caused by the quadratic non-radiative recombination with participation of two molecules, e.g., ionization, but the mechanism of return of the molecules to the neutral state can differ from the one suggested by our model.

\section{Conclusions}

The luminescence intensity of chlorophyll reduces continuously under a prolonged photoexcitation. The intensity degradation rate decreases at low temperatures. The degradation curve is rather well described by a sum of two hyperbolic functions. At room temperature, the luminescent system restores slowly after the irradiation has been stopped, while no restoration is detected at the liquid nitrogen temperature. A simplified model which describes the system luminescence degradation according to the quadratic law is suggested.
1. V.N. Karnaukhov, Luminescent Analysis of Cells (Analit. Mikroskop., Pushchino, 2002) (in Russian).

2. A.M. Silaeva, Structure of Chloroplasts and the Medium Factor (Naukova Dumka, Kyiv, 1978) (in Russian).

3. V.A. Veselovskij and T.V. Veselova, Luminescence of Plants: Theoretical and Practical Aspects (Nauka, Moscow, 1990) (in Russian).

4. N.L. Fateeva, A.V. Klimkin, O.V. Bender et al., Opt. Atmosph. Ocean 19, 212 (2006).

5. O. Vakulenko, O. Grygorieva, O. Dacenko, and V. Zujev, Proceed. of the 11th Intern. Sci. Conf. "Optics and High Technology Material Science," (T. Shevchenko Nat. Univ., Kyiv, 2010), p. 173.

6. B.A. Gulyaev and V.L. Teten'kin, Izv. AN SSSR, Ser. Biol., No. 4, 536 (1983).

Received 19.09.11

\section{ДЕГРАДАЦІЯ ЛЮМІНЕСЦЕНЦІЇ ХЛОРОФІЛУ В РОСЛИНАХ}

О.В. Вакуленко, О.О. Григор'єва, О.І. Даценко

$\mathrm{P}$ е $з$ ю м е

Вивчено явище деградації інтенсивності фотолюмінесценції хлорофілу водної рослини Vallisneria spiralis L. Показано, що деградаційна крива досить добре описується сумою двох гіперболічних функцій. За низьких температур швидкість деградації інтенсивності зменшується. За кімнатної температури 3 припиненням опромінення спостерігалося повільне відновлення люмінесцентної системи. За температури рідкого азоту відновлення не виявлено. Побудовано спрощену модель, яка описує деградацію люмінесценції системи за квадратичним законом. 